Rev. Biol. Trop., 47(4): 763-773, 1999

www.ucr.ac.cr www.ots.ac.cr www.ots.duke.edu

\title{
The influence of humidity, nutrients and light on the establishment of the epiphytic bromeliad Tillandsia guatemalensis in the highlands of Chiapas, Mexico
}

\author{
J. C. Castro Hernández ${ }^{1}$, J. H. D. Wolf ${ }^{2}$, J. G. García-Franco ${ }^{3}$ \& M. González-Espinosa² \\ 1 Instituto de Historia Natural. Apartado Postal 13. C.P. 29000 Tuxtla Gutiérrez, Chiapas, México. \\ 2 El Colegio de La Frontera Sur (ECOSUR), Apartado Postal 63. C.P. 29200 San Cristóbal de Las Casas, Chiapas, \\ México. Fax 5296782322; jwolf @ sclc.ecosur.mx \\ 3 Instituto de Ecología, A.C., Apartado Postal 63. C.P. 91000 Xalapa, Veracruz, México.
}

Received 28-IX-1998. Corrected 5-IV-1999. Accepted 10-V-1999.

\begin{abstract}
In the highlands of Chiapas, rapid habitat destruction and alteration threaten epiphytes. Presumably, forest transformation increases open and border-type vegetation, characterized by drier conditions than those prevailing deeper in the forest. If so, mesic epiphytes should be especially affected. We investigated the role of water availability during the growth of a population of the wide-ranging mesic C3 phytotelm bromeliad Tillandsia guatemalensis. Chiapas experiences a pronounced dry season from November to April when average monthly precipitation falls below $30 \mathrm{~mm}$. T. guatemalensis observed in situ released seeds during this interval and high germination rates occurred about seven weeks after the rainy weather returned (over $93 \%$, an observation confirmed in the laboratory). Many of the tiny seedlings disappeared before they could anchor to the substrate, probably flushed off by torrential rains. Over half of the seedlings comprising a naturally established population died during the dry season. High seedling mortality was also deduced from the size-class structure of natural populations. Seedling mortality on bark taken from the tree base up to a height of $1.3 \mathrm{~m}$ of bigger trees is similar on two species of oak compared to two species of pine. These barks also possessed high water retaining capacity. Oak bark derived from higher up the tree, however, absorbed a larger amount of water per surface area and liberated water during a longer period of time than the bark of Pinus tecunumanii taken from similar locations on the host tree. Additionally, the water retaining capacity of the bark of larger trees was generally greater. We suggest that such differences in water retaining capacity explain, at least in part, why epiphytes favor oaks, the lower parts of pine trees, and larger (older) trees. After the development of the phytotelm growth form, mortality in a natural population falls. Our experiments on phytotelm plants that appeared stressed after being transplanted out of their original habitat suggest that nutrients are limiting growth.
\end{abstract}

Key words: Bromeliaceae, epiphytes, germination, host preference, phytotelm bromeliad, pine-oak forests, plant population structure, seedling establishment.

One of the characteristics of the tropical rain forest is the great abundance of plants growing on canopy trees (e.g., Richards 1952). In wet tropical forest more than half of the individuals of vascular plants may be epiphytes, comprising up to $35 \%$ of all vascular species present in these forests (Gentry \& Dodson 1987). In tropical America, the state of
Chiapas, Mexico, is one of the better botanically explored regions and here, out of a total of 8250 species reported, some 1000 species occur as epiphytes (Breedlove 1986, internal report UNAM). Species diversity is highest at mid-elevations (pers. obs.), consistent with patterns elsewhere (Gentry \& Dodson 1987, Wolf 1993). In contrast, epiphyte abundance is 
greatest at higher elevations (GonzálezEspinosa et al. 1991). At the highlands of Chiapas the standing epiphytic crop, mostly bromeliads, may be $18 \mathrm{~kg}$ dry-weight, possibly exceeding the green biomass of the host tree (Wolf unpubl.).

In addition to uncontrolled harvesting for commercial or ceremonial purposes, habitat destruction and alteration may present an even greater threat to epiphytes (Breedlove \& Laughlin 1993). Deforestation rates in the greater central highlands of Chiapas were estimated at $2.13 \%$ annually for 1984-1990 accompanied by changes in land-use and the current landscape is a mosaic of forest fragments in different states of degradation (Ochoa-Gaona \& González-Espinosa pers. com.). Fragmentation increases border forest characterized by more open and dryer conditions than those prevailing deep in primary forest (e.g. Murcia 1995). Furthermore, the selective logging of the larger trees, the destruction of the understory, and the gathering of fuel wood may further aridify forests. A separate anthropogenic effect is the gradual replacement of oaks by pines in the pine-oak forest, or the 'pinerization' of the landscape (GonzálezEspinosa et al. 1995).

The epiphytic community is especially vulnerable to structural changes of the forest (Turner et al. 1994). Little is known, however, about the processes responsible (Benzing 1994). Changes in humidity, light and nutrient conditions may all play a role (Grubb et al. 1963, Johansson 1974, Valdivia 1977, Benzing 1990, Hietz \& Hietz-Seifert 1995). Moreover, the different bark structure of the pine trees from the oak trees may affect epiphyte success (Benzing 1990).

In this study, by combining field observations with experimental work, we focus on some of these factors acting during the life cycle of Tillandsia guatemalensis L.B. Smith, a widespread mesic phytotelm bromeliad native to the highlands of Chiapas (Fig. 1).

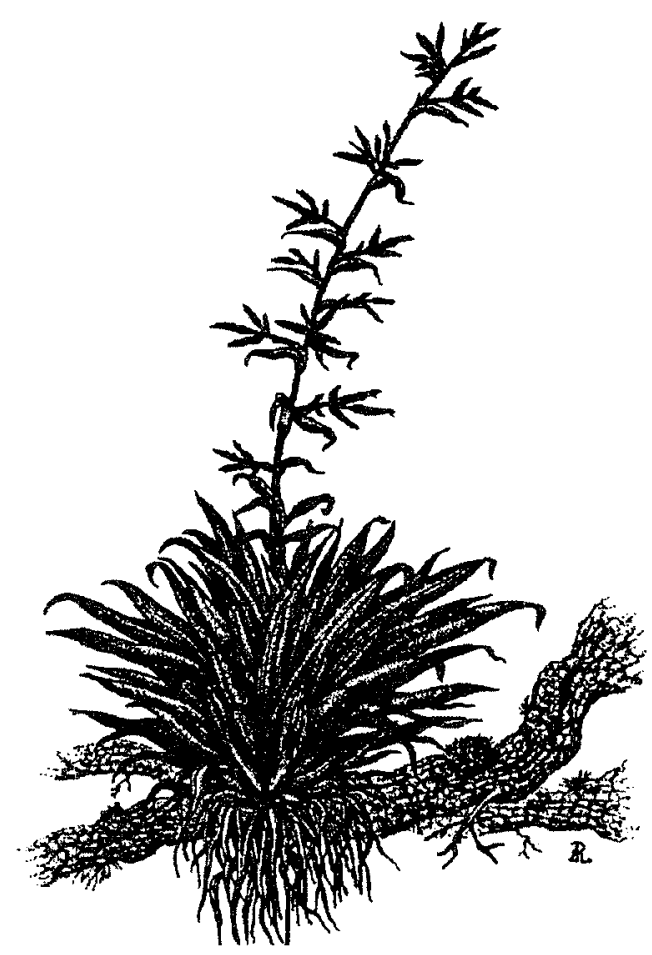

Fig. 1. Habit of an adult individual of the epiphytic bromeliad Tillandsia guatemalensis L.B. Smith.

\section{MATERIALS AND METHODS}

Study area: The highlands of Chiapas $\left(16^{\circ} 30^{\prime}-17^{\circ} 00^{\prime} \mathrm{N}, 92^{\circ} 00^{\prime}-93^{\circ} 00^{\prime} \mathrm{W}\right)$ cover an area of almost 1500000 ha, with elevations between 1650 and $2400 \mathrm{~m}$. Mean annual temperature at San Cristóbal de Las Casas, situated at an altitude of 2,276 m, from 1978-1995 is $14.8{ }^{\circ} \mathrm{C}$ (Comisión Nacional del Agua, unpubl.). Average annual rainfall during this period was $1042 \mathrm{~mm}$ with a pronounced dry season between November and March (Fig. 2). Pine-oak and oak-pine forests are the predominant forest formations, forming a complex mosaic of patches of different formations reflecting differences in resource use (González-Espinosa et al. 1995). 


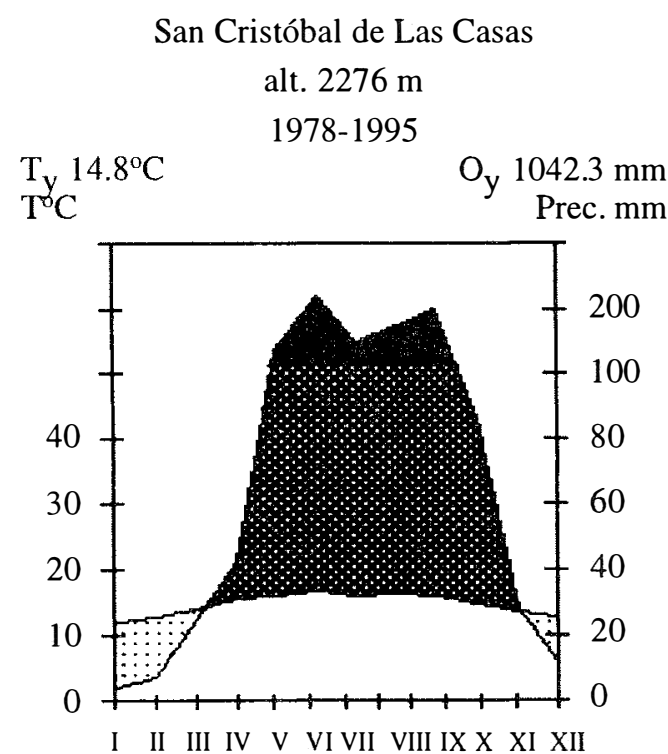

Fig. 2. The climate at San Cristóbal de Las Casas, Chiapas, Mexico, based on a 17 year record. Presentation after Walter (1964)

Methods: From field observations and experiments we obtained data on population structure, germination, seedling mortality, and growth under varying nutrient and light conditions of the epiphytic bromeliad $T$. guatemalensis. A voucher specimen has been deposited in the herbarium at ECOSUR, Wolf 2550).

The structure of a natural population was assessed in April 1996. We measured the length of every bromeliad anchored on a $5 \mathrm{~m}$ tall Quercus rugosa Nee tree with a trunk of 20 $\mathrm{cm}$ DBH. We divided the population in size classes according to apparent morphologic differences, following Benzing (1978).

Seed germination was evaluated both in the field and under laboratory conditions. In the understory of an oak forest we vertically suspended squares of $100 \mathrm{~cm}^{2}$ of cut out segments of bark from the base, the trunk, or the branches. We used barks of Pinus tecunumanii Eguiluz \& J.P. Perry (=Pinus oocarpa var. ochoterenai Martínez), P. pseudostrobus Lindley and $Q$. rugosa trees. Bark segments were submerged in water for 24 hours before suspension in the forest in January 1996. On each segment, we seeded 25 seeds of $T$. guatemalensis collected from a single inflorescence. We weighed the bark segments on a monthly basis, and assume that variations in weight largely reflect changes in water content. Simultaneously, we placed 25 seeds from the same plant on filter paper in covered Petri dishes that were exposed to direct sunlight (10) or maintained in diffuse light (another 10). Seedling mortality after germination was monitored. The fate of $T$. guatemalensis seedlings was also followed in a naturally established population, from December 1995 until the end of the next year. We counted all plants $<2 \mathrm{~cm}$ in height on the tree base and trunks up to a height of $130 \mathrm{~cm}$. We sampled 12 full-grown host trees, $\mathrm{DBH}>20 \mathrm{~cm}$, equally divided over two species of pine trees, Pinus pseudostrobus and Pinus tecunumanii, and to two species of oak, Quercus rugosa and Q. laurina. Distances between trees exceeded $50 \mathrm{~m}$.

The effect of nutrients and light on the growth of adult $T$. guatemalensis plants was evaluated both inside and outside the greenhouse. In July 1996, we collected 432 plants ranging from 14 to $30 \mathrm{~cm}$ in height in a pineoak forest at $2450-2500 \mathrm{~m}$ elevation. We rinsed the plants in order to remove accumulated humus and subjected groups of nine randomly selected plants to a combination of treatments in a randomized complete block design. Within each group plants were randomly moved to avoid an edge effect. Light was blocked with netting that resulted in a photosynthetic active radiation at midday as compared with outside light of $35 \%, 41 \%$, and $78 \%$ in the greenhouse, and of $40 \%, 48 \%$ and $100 \%$ in the open. Nutrient treatments were: ammonium nitrate, phosphate, and N-P-K 20-20-20, applied in solution of $600 \mathrm{mg} / \mathrm{l}$, directly in the tank, and in weekly dosages of $6 \mathrm{mg}$. The tanks were rinsed two days after each application. We used a general linear regression model to estimate the standing crop of plants, using plants from the same source. The following independent variables were entered in the model: number of leaves, maximum leaf length, width at midpoint along the blade of the longest leaf, 
base diameter, and the maximum width of the cup(all measurements in $\mathrm{cm}$ ).

For plants with dry weight $\geq 2.5 \mathrm{~g}\left(\mathrm{n}=25 ; \mathrm{R}^{2}=0.904\right.$; $\mathrm{p}=0.000$ ):

dry weight $(\mathrm{g})=$ leaf number $(0.272)+$ leaf length $(0.0563)+$ leaf width $(1.339)+$ base diameter $(-0.301)+$ cup diameter (0.082)-17.381.

For plants with dry weight $<2.5 \mathrm{~g}\left(\mathrm{n}=19 ; \mathrm{R}^{2}=0.900\right.$; $\mathrm{p}=0.000$ ):

dry weight $(\mathrm{g})=$ base diameter $(0.838)-0.796$

We estimated the relative growth rate (RGR) in mg. $\mathrm{g}^{-1}$ day $^{-1}$ between consecutive measurements by means of

RGR $=\begin{array}{ll}1 & \mathrm{dW} \\ \mathrm{W}_{\mathrm{av}} . & \mathrm{dt}\end{array}$

where $\mathrm{W}=$ dry weight and Wav. = average dry weight during the measuring period.

Growth between treatments was analized with a nested ANOVA.

The kind of metabolic pathway of seedlings of $T$. guatemalensis was deduced from the daily fluctuations in acidity (Osmond et al. 1989). We determined the acidity of three samples of the ground tissue of seedlings each at $07.00,15.00,20.00$ and 01.00 hours. The seedlings measured less than $2.5 \mathrm{~cm}$ in height. This procedure was repeated with $T$. usneoides, a known CAM bromeliad (Martin et al. 1981)

\section{RESULTS}

We found 512 bromeliad specimens on a single Quercus rugosa tree, ranging in size from 0.29 to over $100 \mathrm{~cm}$ (5.12 individuals $/ \mathrm{dm}^{2}$ including some flowering adults. In addition, we registered 121 seeds. All plants greater than $10 \mathrm{~cm}$ were $T$. guatemalensis, so we assumed that no other species of bromeliad was present, even though small seedlings defied identification. The frequency distribution by size class is unimodal with its maximum in the seedling size class of between 1 and $2 \mathrm{~cm}$ (Fig. 3). number of

individuals

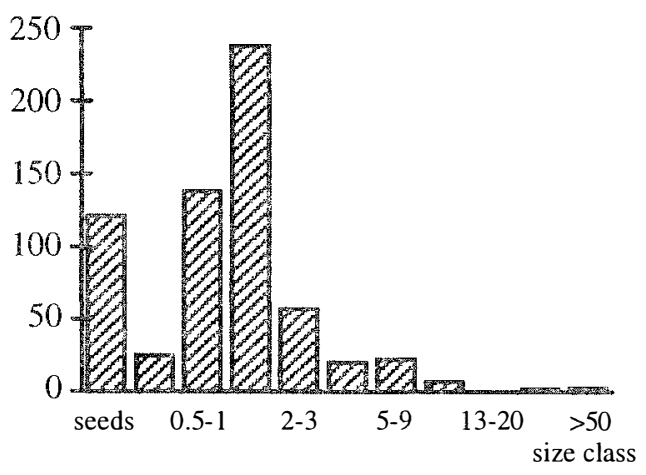

Fig. 3. Frequency distribution of size classes in April of a population of Tillandsia guatemalensis on a Quercus rugosa host tree. The size class of over $50 \mathrm{~cm}$ includes flowering plants.

Seed failed to germinate on the initially water saturated bark segments under field conditions until June, six months after the sawing and two months after the beginning of the wet season, nevertheless germination was high $(93-100 \%)$. Germination was not different between tree species nor between origin of the bark segments on the tree (ANOVA, $p$ $>0.10$ ). Bark segments gradually lost weight from the beginning of the experiment in January up to April, the end of the dry season (Table 1). With the exception of the higher tree zones of Pinus tecunumanii, the bark at the base, trunk or branches from trees with DBH $>20 \mathrm{~cm}$ could hold more water than bark of younger trees from the same tree zone. Accordingly, these bark segments lost more weight during the dry season and for a longer period of time. The same pattern was observed when comparing oak bark with the bark of the two species of pine. For example, between February and March the oak and pine bark segments of the base 1ost, respectively, 38.45 and $7.35 \mathrm{~g}$ of weight on average, presumably due to water loss. In June the segments were again at near their ongmal weight, sometimes showing even higher values than after 24 hours of submergence, and 
remained more or less constant in water content until the start of a next dry period in November. Under laboratory conditions, germination occurred after seven weeks and again success was high, $98.0 \%$ in direct light and $97.6 \%$ in diffuse light. After six months all seedlings remained alive and averaged $0.58 \mathrm{~cm}$ in height and supported up to 13 leaves.

\section{TABLE 1}

Monthly increases (+) or decreases (-) of weight $(\mathrm{g})$ of bark segments under field conditions. Values are in comparison with the month before; *Ianuary represents the water absorption of oven-dried bark after submergence for 24 hours

\begin{tabular}{|c|c|c|c|c|c|c|c|c|c|c|c|c|c|c|c|c|}
\hline \multicolumn{4}{|c|}{ Bark segments } & \multicolumn{13}{|c|}{ Amount of released $(-)$ or absorbed $(+)$ water } \\
\hline Species & $\begin{array}{l}\text { DBH } \\
(\mathrm{cm})\end{array}$ & Zone & $\begin{array}{l}\text { Dry- } \\
\text { veight }\end{array}$ & $\begin{array}{l}\text { Jan.* } \\
\text { g) }\end{array}$ & Feb. & Mar. & April & Total & May & June & July & Aug. & Sep. & Oct. & Nov. & Dec. \\
\hline Pinus & $<10$ & Base & 24.7 & 11.3 & -6.1 & -1.6 & 0.8 & -6.9 & 1.4 & 22.3 & -5.8 & 0.8 & 1.3 & -14.0 & -3.5 & \\
\hline \multirow[t]{5}{*}{ tecunumar } & & Trunk & 15.7 & 26.9 & -21.7 & -1.0 & 0.3 & -22.4 & 1.1 & 19.8 & -4.6 & 1.5 & 2.2 & -15.7 & -3.2 & -0.7 \\
\hline & & Branch & 20.6 & 31.5 & -26.5 & 0.1 & 0.1 & -26.3 & 0.8 & 26.3 & -6.5 & 2.3 & 3.9 & -17.2 & -6.1 & -4.5 \\
\hline & $>20$ & Base & 218.4 & 102.6 & -48.5 & -13.6 & 0.1 & -62.0 & 6.7 & 76.9 & -4.4 & 3.3 & 8.2 & -32.4 & -59.9 & -34.1 \\
\hline & & Truak & & 13.7 & -8.1 & -1.0 & 0. & & 1.0 & 18.2 & -1.9 & 0.9 & 0.9 & -12.5 & -4.8 & -0.9 \\
\hline & & & & 16.4 & -13.4 & -0.4 & 0.0 & -13.8 & 0.5 & 9.2 & -2.8 & 0.0 & -0.1 & -2.1 & -2.3 & -1.8 \\
\hline \multirow{6}{*}{$\begin{array}{l}\text { Pinus } \\
\text { pseudosiro }\end{array}$} & $<10$ & & & & & -3.0 & & & 2.6 & 33.5 & -8 & 1.0 & 3.9 & -17.9 & -8.2 & -3.7 \\
\hline & & Trunk & 23.2 & 20.0 & -10.5 & -1.5 & -3.4 & -15.4 & 1.0 & 18.5 & -2.9 & 1.2 & 2.3 & -8.2 & -6.9 & -1.1 \\
\hline & & Branc & 25.5 & 10.9 & -6.6 & -0.7 & & -6.2 & 1.1 & 24.8 & -7.4 & -0.3 & -0.3 & -10.3 & -5.2 & -1.9 \\
\hline & $>20$ & Base & 320. & 87.7 & -27.1 & -11.2 & 0. & -37.6 & 27.8 & 46.9 & -19.7 & 5.1 & 12.9 & -22.6 & -21.0 & -16.3 \\
\hline & & & & 36.3 & & -2.5 & -0.1 & -26.1 & 6.5 & 32.8 & -4.4 & 1.6 & 2.8 & -15.2 & -15.4 & -7.8 \\
\hline & & ranch & 32.6 & 18.5 & -10.8 & -1.8 & 1.1 & -11.5 & 2.4 & 26.8 & -7.1 & 1.0 & 4.6 & -14.3 & -7.9 & -4.4 \\
\hline \multirow{6}{*}{$\begin{array}{l}\text { Quercus } \\
\text { rugosa }\end{array}$} & $<10$ & Base & & 97.2 & -40.4 & -34.0 & -3 & -78.1 & 12.9 & 60.3 & -1.7 & 2.4 & 1.3 & -14.3 & -14.6 & -13.2 \\
\hline & & Trunk & 16 & 28.7 & -19.7 & -2.9 & 0 & -22.6 & 5.5 & 18.5 & -7.3 & 0.2 & 1.2 & -11.2 & -4.4 & -0.8 \\
\hline & & Branch & & 25.5 & -19.6 & -0.6 & 0.0 & -20.2 & 0.8 & 21.7 & -4.4 & -0.2 & -0.2 & -10.6 & -5.7 & -2.1 \\
\hline & 20 & Base & 107.7 & 164.6 & -65.8 & -42.9 & -20.1 & -128.8 & 23.9 & 104.5 & -2.6 & 0.3 & 0.5 & -12.9 & -16.7 & -13.1 \\
\hline & & & 76.7 & 103.5 & -47.6 & -23.9 & & -82.5 & 11.8 & 99.2 & -1.0 & -1.5 & -3.6 & -40.5 & -29.1 & -14.2 \\
\hline & & & 42.3 & 53.6 & -29.6 & -15.6 & 0.9 & -44.3 & 6.5 & 45.1 & -6.4 & -0.5 & -0.6 & -22.6 & -6.9 & -4.7 \\
\hline
\end{tabular}

In contrast, the mortality of seedlings on the suspended bark segments in situ was high and seven months after germination only $19.4 \%$ of the sample of 289 remained alive (Table 2). Desiccation appeared to have little influence on mortality during this rainy period becalise dried out specimens were never found. Instead, seedlings typically vanished between observations together with small pieces of sloughing and disintegrating bark to which they were attached. Desiccation was a major factor of seedling mortality, however, in a natural population of seedlings on living, more stable, bark, where mortality was also high (Fig. 4). Here, out of an initial number of 185 seedlings, only $34.5 \%$ survived after one year. Mortality in this population was highest during the first montins of the year, a period not cov- ered in the bark segment experiment $(56.36 \%$ up to April). During the rest of the year, after the beginning of the rainy season, most seedlings survived. Also from April on, recruitment of new seedlings occurred, 81 in total. On the lower part of these trees, seedling density and survival on pine and oak trees was similar, except for Pinus tecunumanii where the seedlings attached displayed a lower mortality.

Plants grown outdoors grew significantly faster than those in the greenhouse during both sampling periods, July-September and September-November (Student's t, $p=0.000$ and $p=0.006$, Table 3 ). Growth always slowed significantly (Student's t, $p=0.000$ ) during the second period. Plants in the greenhouse grew? fastest under $4 \%$ full exposure (Tables 3 and 4). Outdoors, radiation had no significant 
TABLE 2

Number of remaining seeds in June $(N)$, seedling germination (\%), and subsequent seedling mortality on bark-segments of different species, trunk diameters, and origin on the host tree

\begin{tabular}{|c|c|c|c|c|c|c|c|c|c|c|c|}
\hline \multirow{2}{*}{$\begin{array}{l}\text { Species of } \\
\text { host tree }\end{array}$} & \multirow{2}{*}{$\begin{array}{l}\mathrm{DBH} \\
(\mathrm{cm})\end{array}$} & \multirow{2}{*}{$\begin{array}{l}\text { Tree- } \\
\text { zone }\end{array}$} & \multirow[t]{2}{*}{$\mathrm{N}$} & \multirow[t]{2}{*}{$\%$} & \multicolumn{7}{|c|}{ Seedling Mortality (\%) } \\
\hline & & & & & June & July & Aug. & Sep. & Oct. & Nov. & Dec. \\
\hline & $<10$ & Base & 21 & 95.2 & 4.8 & 4.8 & 9.5 & 9.5 & 9.5 & 14.3 & 19.0 \\
\hline & & Trunk & 17 & 100.0 & 0.0 & 29.4 & 58.8 & 70.6 & 76.5 & 88.2 & 88.2 \\
\hline & & Branch & 16 & 93.8 & 6.3 & 6.3 & 18.8 & 50.0 & 62.5 & 81.3 & 100.0 \\
\hline & $>20$ & Base & 22 & 90.9 & 9.1 & 27.3 & 36.4 & 59.1 & 72.7 & 81.8 & 86.4 \\
\hline & & Trunk & 15 & 100.0 & 0.0 & 0.0 & 20.0 & 53.3 & 66.7 & 73.3 & 80.0 \\
\hline & & Branch & 14 & 92.9 & 7.1 & 42.9 & 57.1 & 100.0 & 100.0 & 100.0 & 100.0 \\
\hline Pinus & $<10$ & Base & 17 & 100.0 & 0.0 & 29.4 & 29.4 & 64.7 & 82.4 & 88.2 & 94.1 \\
\hline \multirow[t]{5}{*}{ pseudostrobus } & & Trunk & 13 & 100.0 & 0.0 & 23.1 & 30.8 & 61.5 & 61.5 & 76.9 & 84.6 \\
\hline & & Branch & 27 & 92.6 & 7.4 & 33.3 & 63.0 & 92.6 & 96.3 & 96.3 & 100.0 \\
\hline & $>20$ & Base & 6 & 100.0 & 0.0 & 0.0 & 33.3 & 66.7 & 66.7 & 66.7 & 100.0 \\
\hline & & Trunk & 15 & 100.0 & 0.0 & 0.0 & 13.3 & 40.0 & 40.0 & 40.0 & 40.0 \\
\hline & & Branch & 17 & 94.1 & 5.9 & 17.6 & 52.9 & 64.7 & 76.5 & 88.2 & 94.1 \\
\hline Quercus & $<10$ & Base & 13 & 92.3 & 7.7 & 7.7 & 23.1 & 69.2 & 69.2 & 69.2 & 69.2 \\
\hline \multirow[t]{5}{*}{ rugosa } & & Trunk & 12 & 100.0 & 0.0 & 8.3 & 8.3 & 91.7 & 91.7 & 91.7 & 100.0 \\
\hline & & Branch & 15 & 100.0 & 0.0 & 0.0 & 0.0 & 6.7 & 33.3 & 53.3 & 66.7 \\
\hline & $>20$ & Base & 15 & 100.0 & 0.0 & 6.7 & 33.3 & 73.3 & 73.3 & 73.3 & 73.3 \\
\hline & & Trunk & 13 & 100.0 & 0.0 & 0.0 & 15.4 & 38.5 & 53.8 & 61.5 & 69.2 \\
\hline & & Branch & 21 & 90.5 & 9.5 & 33.3 & 57.1 & 81.0 & 81.0 & 85.7 & 85.7 \\
\hline
\end{tabular}

mortality (\%)

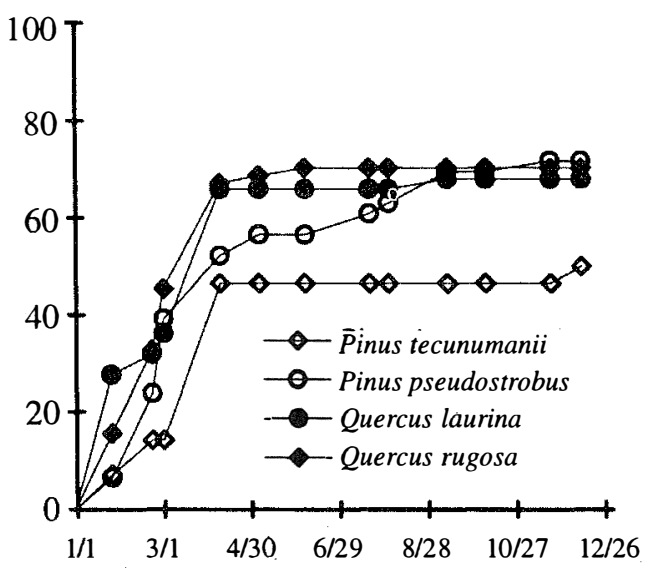

date

Fig. 4. Seedling mortality during 1996 of a naturally established population of Tillandsia guatemalensis on different species of host trees in an oak-pine forest. Only plants $<2 \mathrm{~cm}$ in height are included. Initial seedling densities on Pinuspseudostrobus, $P$. tecunumanii, Quercus laurina and $Q$. rugosa were $0.21,0.67,0.39$ and 0.13 seedlings $/ \mathrm{dm}^{2}$, respectively. influence during the first period, but during the second period growth was slowest under $40 \%$ exposure. Balanced fertilizer always best promoted growth. Interactions between light and nutrients were not significant (Table 4).

Acidity analysis of the tissue of seedlings of $T$. guatemalensis indicated that juveniles utilize the $\mathrm{C} 3$ metabolism like the adult (Table 5).

\section{DISCUSSION}

In the development of a plant population we may recognize distinct phases: dispersal, germination, seedling establishment (anchoring for epiphytes), seedling growth, vegetative growth, and reproduction (Harper 1977). Critical environmental variables influence the transition into a next phase, independent of intra-specific factors. 
TABLE 3

Relative Growth Rate $\left(m g . g^{-1} \cdot\right.$ day $\left.^{-1}\right)$ of Tillandsia guatemalensis plants grown in the greenhouse and outdoors under different levels of radiation and nutrient regimes

$\begin{array}{lccc}\text { Greenhouse } & & \text { July-Sep. } & \text { Sep.-Nov. } \\ \text { Light } & 41 \% & 5.091 & 2.012 \\ & 35 \% & 3.281 & 1.431 \\ & 48 \% & 3.638 & 1.419 \\ \text { Nutrients } & \text { none } & 3.284 & 0.498 \\ & \text { Phosphate } & 4.067 & 0.039 \\ & \text { Nitrate } & 3.803 & 0.252 \\ & \text { N-P-K } & 4.889 & 2.126 \\ \text { Outdoors } & & & \\ \text { Light } & 78 \% & 5.019 & 3.654 \\ & 40 \% & 6.696 & 1.947 \\ & 100 \% & 6.467 & 4.092 \\ \text { Nutrients } & \text { none } & 6.169 & 1.287 \\ & \text { Phosphate } & 5.534 & 1.813 \\ & \text { Nitrate } & 5.506 & 0.707 \\ & \text { N-P-K } & 7.025 & 3.669\end{array}$

TABLE 4

ANOVA of the influence of relative amount of daylight at midday, and nutrient levels on relative growth rates

$\begin{array}{lccccc}\text { Greenhouse (n=211) } & \text { ss } & \text { df } & \text { mss } & \text { F } & \text { P } \\ \text { July-Sep. } & & & & & \\ \text { Light } & 0.0 & 2 & 0.0 & 5.18 & 0.006 \\ \text { Nutrients } & 0.0 & 3 & 0.0 & 1.20 & 0.126 \\ \text { Light x Nutrients } & 0.0 & 6 & 0.0 & 0.36 & 0.905 \\ \text { Residual } & 3.0 & 199 & 0.0 & & \\ \text { Sep.-Nov. } & & & & & \\ \text { Light } & 0.0 & 2 & 0.0 & 15.33 & 0.000 \\ \text { Nutrients } & 0.0 & 3 & 0.0 & 3.55 & 0.015 \\ \text { Light x Nutrients } & 0.0 & 6 & 0.0 & 0.87 & 0.521 \\ \text { Residual } & 3.0 & 199 & 0.0 & & \\ \text { Outdoors (n=214) } & & & & & \\ \text { July-Sep. } & & & & & \\ \text { Light } & 0.0 & 2 & 0.0 & 4.04 & 0.019 \\ \text { Nutrients } & 0.0 & 3 & 0.0 & 1.91 & 0.130 \\ \text { Light x Nutrients } & 0.0 & 6 & 0.0 & 0.87 & 0.521 \\ \text { Residual } & 3.0 & 202 & 0.0 & & \\ \text { Sep.-Nov. } & & & & & \\ \text { Light } & 0.0 & 2 & 0.0 & 14.18 & 0.000 \\ \text { Nutrients } & 0.0 & 3 & 0.0 & 5.48 & 0.001 \\ \text { Light x Nutrients } & 0.0 & 6 & 0.0 & 0.67 & 0.673 \\ \text { Residual } & 3.0 & 202 & 0.0 & & \end{array}$

\section{TABLE 5}

The daily variation in tissue acidity of seedlings of Tillandsia guatemalensis. Acidity is expressed as mequiv.g-1 dry weight. As control the values for $\mathrm{T}$. usneoides, a known CAM plant, are also given. The difference from the mean value is low at any time for $\mathrm{T}$. guatemalensis, and significantly different between the two species $(p<0.01)$, strongly suggesting that $\mathrm{T}$. guatemalensis seedlings do not use the CAM pathway

\begin{tabular}{lrrrr}
\multicolumn{1}{c}{ Time of day } & 07.00 & 15.00 & 20.00 & 01.00 \\
Tillandsia guatemalensis & 361 & 392 & 423 & 398 \\
Tillandsia uneoides & 674 & 440 & 397 & 354
\end{tabular}

Tillandsia guatemalensis disperses seeds in the highlands of Chiapas during the dry season. Seed establishment of the plumed seeds is likely to decrease with distance from the parent, as shown for another epiphytic bromeliad, Tillandsia deppeana (García-Franco \& RicoGray 1988). These authors discussed the role of winds and whether the host trees are deciduous or evergreen. In addition, heavy rains may flush aggregated clumps of wet coma haired seeds to the ground (J. Wolf, pers. obs.).

The germination of seeds was highly successful, both in the laboratory and under field conditions in the forest understory. High laboratory germination was also observed in another epiphytic bromeliad, Tillandsia circinnata ( $=T$. paucifolia $)$, however, germination of this species in forested sites in the state of Florida was extremely poor, c. 3\% (Benzing 1978). Possibly frequent wetting and/or constant air high humidity is required. In Tillandsia guatemalensis germination occurred in situ after some seven weeks of the beginning of the rainy season. Occasional precipitation during the dry season was not sufficient to initiate germination. Light may also be required to germinate epiphytic bromeliads (Benzing 1990). In our laboratory experiment we found no difference in germination of seeds under diffuse or direct light.

Survival of the seedlings in a natural population was high during the rainy season, but during the few dry months of the year more than one half of the plants died (Fig. 4). High juvenile mortality was also apparent in the 
demographic structure of a natural population (Fig. 3). As pointed out by Benzing (1990), seedlings are likely to desiccate faster than adult plants, simply because of their less favorable surface/volume ratio and small size. Juveniles of tank-forming tillandsioid species are often characterized by succulent leaves and a dense indumentum of trichomes and are structurally more similar to adult atmospheric type tillandsioid species (Adams \& Martin, 1986). These morphological forms may enhance the survival of juvenile $T$. guatemalensis during the dry season.

The age-size class of $1-2 \mathrm{~cm}$ contains more individuals than the younger class of $0.5-1 \mathrm{~cm}$. Interestingly, Benzing (1978) describes a similar frequency distribution pattern in populations of epiphytic $T$. circinnata. One explanation could be to assume a previously higher recruitment. Benzing (1978), however, finds it more likely that the size class with the highest number of individuals comprises numerous cohorts of different ages due to unequal growth rates.

Once the juvenile plants grow to over 2 $\mathrm{cm}$ tall mortality slows (Fig. 3). Such plants have already formed the characteristic phytotelm growth form, providing an additional source of water to draw from during the dry season. A high initial growth rate during the first seven months before the start of the dry season would thus appear to be advantageous, but more difficult to attain if seedlings make use of the CAM photosynthetic pathway. In seedlings there is an apparent trade-off between water conservation (CAM) and relatively vigorous growth (C3). Some bromeliads may switch between CAM and C3 (Medina et al. 1977), but tissue acidity analysis of $T$. guatemalensis seedlings through titration shows that the xeromorphic juveniles already exhibit the C3 photosynthesis of the adult (Table 5).

Seedling survival and seedling density of plants anchored to the base and lower part of the trunk is similar between the observed oaks and pines (Fig. 4). Mature oak forests, however, support a more abundant epiphytic vegetation than pine forests (González-Espinosa et al. 1991). The preference of epiphytes for oaks is possibly due to differences in bark humidity, roughness, stability, porosity, chemistry or other factors (e.g., Johansson 1974). In our field germination experiment we observed differences in the water budget of segments of oak and pine bark. Saturated Quercus rugosa bark released a larger amount of water during the dry season and over a longer interval than the pine barks (Table 1). Since seedling mortality in a natural population occurs largely during the dry season, these differences in the water holding capacity between the oak and pine barks may help explain the higher abundance of $T$. guatemalensis on oak. This postulation assumes that liberated bark water increases the humidity of the air enveloping the bark and that seedlings benefit. Our observation that seedling mortality on pines was not higher than that on oaks is consistent, since only seedlings on the lower part of trees with a trunk of over $20 \mathrm{~cm} \mathrm{DBH}$ were considered. In these locations the species of pine have an unusually thick bark with a water retaining capacity comparable to that of oak bark (Table 1). Pinus tecunumanii trees that generally are devoid of canopy bromeliads often support high abundances of bromeliads and other epiphytes at their base. On a larger scale, the geographical distribution of bromeliads in the Andes of Ecuador has also been attributed to differences in water availability during the year (Gilmartin 1973).

The bark of the larger trees, specifically that of Quercus rugosa, holds more water than trees with $\mathrm{DBH}<10 \mathrm{~cm}$ (Table 1). It has repeatedly been reported that larger trees support more individuals and species of epiphytes than smaller ones (e.g. Catling \& Lefkovitch 1989, Ter Steege \& Cornelissen 1989, Zimmerman \& Olmsted 1992, Ingram \& Nadkarni 1993, Wolf 1994, Hietz \& HietzSeifert 1995, Hietz et al. 1996). These patterns are attributed to the presence of a greater bark surface area, more time for colonization and subsequent development, and to habitat factors. As to the latter, our data on seasonal mortality and bark characteristics suggest that a 
thickening of the bark of the older trees may play a role through enhancing its water retaining capacity.

While mortality in a natural established population during the wet season was low, mortality of the seedlings on the suspended bark segments during the same period was unexpectedly high and showed no clear correlation between either species or original location within the tree (Table 3). Because we did not find dried out specimens we do not attribute great mortality to desiccation. Seedlings just seemed to disappear, and especially so between August and September, suggesting a common external factor such as herbivory, exfoliation of small pieces of bark, or the removal by torrential rains. As to the latter, the tiny newly germinated seedlings are likely susceptible to dislodgment, since they still lack roots. In contrast, the generally larger seedlings in the natural population were securely anchored to their substrate.

After the seedling develops into a water impounding phytotelm bromeliad, mortality is low and water availability is probably a less critical factor (Fig. 3). This is furthermore suggested by other morphological changes in the plant. The leaves become less coriaceous and drop nearly all of their trichomes. Adults use C3 photosynthesis, which allows for a relatively rapid growth. This is also evident from our growth experiments. Under conditions of most rapid growth, balanced fertilizer and outdoors, the daily increment in biomass was $7.025 \mathrm{mg} / \mathrm{g}$ (Table 3). At this rate and with continuous growth it would take a seedling of $1 \mathrm{~g} 1.78$ years only to attain a dry weight of $94 \mathrm{~g}$, an average value at which flowering occurs. Since growth is probably reduced during the dry season, under natural conditions it would take a plant longer to reach adulthood. It seems reasonable to assume that $T$. guatemalensis seedlings may produce a first inflorescence in 4-5 years. However, most plants did not develop this fast and average daily growth from JulyNovember was $3.15 \mathrm{mg} . \mathrm{g}^{-1}$ at which rate, and with uninterrupted growth during the dry season, it would take a $1 \mathrm{~g}$ seedling 3.96 years to attain adulthood. Such slow growth suggests that the plants were stressed. Moreover, the decrease in growth during the second period of the experiment shows that the plants were not developing optimally. Possibly the plants were stressed as a consequence of the transplantation out of the forest. Differences between the mesic forest climate and the experimental conditions were the greatest in the greenhouse where the temperature occasionally exceeded $30^{\circ} \mathrm{C}$ and where air movement was limited. It is in the greenhouse where the plants grew the least. Part of the reduction in growth is also artificial as a consequence of the method used. The outer leaves of this bromeliad naturally desiccate, a process which began in our experiment in September. Since we only included green leaves in the regression analysis to estimate the biomass of plants, real standing crop was underestimated as the experiment progressed.

Outdoor and greenhouse plants grew best, independent from radiation, when provided a balanced fertilizer. Thus, even though the outdoor plants were not sheltered from precipitation and dust input, nutrients were limiting. Whereas these results confirm other observations that nutrients limit bromeliad growth (Benzing 1990), it should be kept in mind that in our experiment all plants apparently grew under stressful conditions.

This preliminary study shows the great impact desiccation may have on the development of a population of $T$. guatemalensis in a region characterized by a hyper seasonal climate. Germination success, seedling mortality, population structure and a greater abundance on larger trees and on oaks as compared to pines, may all be explained by water-availability. However, after the plants have developed the foliar impoundment our results indicate that nutrient supply becomes the primary limiting resource.

\section{ACKNOWLEDGEMENTS}

This research was financed by the Consejo Nacional de Ciencia y Tecnologia 
(CONACyT) through a scholarship to JCCH, the Sistema de Investigación 'Benito Juarez' (SIBEJ), the Ford Foundation and ECOSUR. We thank Duncan Golicher for his advise and comments during all phases of the project. PRONATURA Chiapas kindly granted us access to the Cerro Huitepec Ecological Reserve and The Centro de Desarrollo Comunitario "La Albarrada" (DIF-Chiapas) provided us with a greenhouse. We acknowledge the support of UNICACH, where the laboratory analysis were preformed. Finally, we are grateful for the valuable comments by an anonymous reviewer.

\section{RESUMEN}

En los Altos de Chiapas, la rápida destrucción y alteración del hábitat amenaza a las epífitas. Aparentemente, la transformación del bosque incrementa la vegetación abierta y de borde, caracterizada por condiciones más secas que las prevalecientes en el interior del bosque. De acuerdo con esto, las epífitas mésicas serían especialmente afectadas. Investigamos el papel de la disponibilidad de agua durante el crecimiento de una población de la ampliamente distribuida bromelia fitotelma mésica C3 Tillandsia guatemalensis. Chiapas presenta una pronunciada estación seca entre noviembre y abril, cuando las plantas observadas en el campo liberaron sus semillas. La germinación en altos porcentajes (arriba del 93\%, observación confirmada en laboratorio) se presentó siete semanas después del inicio de las lluvias. Muchas de las livianas plántulas desaparecieron antes de poderanclarse al sustrato, probablemente arrastradas por las lluvias torrenciales. Más de la mitad de las plántulas de una población establecida naturalmente murió durante la estación seca. Esta alta mortalidad se puede deducir también de la distribución de tamaños en una población natural. La mortalidad de plántulas sobre cortezas de árboles grandes, de la base del tronco hasta una altura de $1.3 \mathrm{~m}$, es similar sobre dos especies de encino comparada con dos especies de pino. Estas cortezas también mostraron una alta capacidad de retención de agua. Sin embargo, la corteza de encino de las partes altas en el árbol absorbió mayor cantidad de agua por superficie y liberó agua durante un mayor período de tiempo que las cortezas equivalentes de Pinus tecunumanii. Además la capacidad de la corteza de absorber agua por lo general fue mayor en los árboles más grandes. Sugerimos que las diferencias en la absorción de agua pueden explicar, al menos en parte, la "preferencia" de las epífitas por árboles de encinos, la parte inferior de árboles de pino y los árboles más grandes (más viejos). La mortalidad en una población natural decrece después del desarrollo de la típi- ca forma fitotelma. Nuestros experimentos con plantas fitotelmas, aparentemente estresadas después de ser transplantadas fuera de su hábitat original, sugieren que los nutrientes limitan su crecimiento.

\section{REFERENCES}

Adams, W.W., III \& C. E. Martin. 1986. Morphological changes accompanying the transition from juvenile (atmospheric) to adult (tank) forms in the Mexican epiphyte Tillandsia deppeana (Bromeliaceae). Amer. J. Bot. 73: 1207-1214.

Benzing, D. H.1978. Germination and early establishment of Tillandsia circinnata Schlecht. (Bromeliaceae) on some of its hosts and other supports in southern Florida. Selbyana 5: 95-106.

Benzing, D. H. 1978. The population dynamics of Tillandsia circinnata (Bromeliaceae) cypress crown colonies in Southern Florida. Selbyana 5: 256-263.

Benzing, D. H. 1990. Vascular epiphytes. General biology and related biota. Cambridge University, Cambridge. $354 \mathrm{pp}$.

Benzing, D. H. 1994. How much is known about Bromeliaceae in 1994? Selbyana 15: 1-7.

Breedlove, D. E. 1981. Flora of Chiapas. Part I. Introduction to the flora of Chiapas. The California Academy of Sciences Press, San Francisco, California.

Breedlove, D. E. 1986. Listados florísticos de México IV. Flora de Chiapas. Instituto de Biólogia, Universidad Nacional Autónoma de México, México, D.F. México.

Breedlove, D. E. \& R. M. Laughlin. 1993. The flora, p. 115-200. In D. E Breedlove \& R. M. Laughlin (eds.). The flowering of man. A tzotzil botany of Zinacantán. Vol. I. Smithson. Contr. Anthropol. 35, Washington, D.C.

Catling P. M. \& L. P. Lefkovitch. 1989. Associations of vascular epiphytes in Guatemalan cloud forest. Biotropica 21: 35-40.

García-Franco, J. G. \& V. Rico-Gray. 1988. Experiments on seed dispersal and deposition patterns of epiphytes. The case of Tillandsia deppeana Steudel (Bromeliaceae). Phytologia 65: 73-78.

Gentry, A. M. \& C. H. Dodson. 1987. Contribution of nontrees to species richness of a tropical rain forest. Biotropica 19: 149-156. 
Gilmartin A. J. 1973. Transandean distributions of Bromeliaceae in Ecuador. Ecology 54: 1389-1393.

González-Espinosa, M., P. F. Quintana-Ascencio, N. Ramírez-Marcial \& P. Gaytán-G. 1991. Secondary succesion in disturbed Pinus-Quercus forests in the highlands of Chiapas, Mexico. J. Veg. Sci. 2: 351360 .

González-Espinosa, M., S. Ochoa-Gaona, N. RamírezMarcial \& P. F. Quintana-Ascencio. 1995. Current land use trends and conservation of the old-growth forest habitats in the highlands of Chiapas, Mexico. p. 190-198. In M. H. Wilson \& S. A. Sader (eds.) Conservation of Neotropical Migratory Birds in Mexico. Maine Agric. Forest Exp. Sta., Misc. Publ. 727.

Grubb, P. J., J. R. Lloyd \& T. D. Pennington. 1963. A comparison of montane and lowland rain forest in Ecuador. I. The forest structure, physiognomy, and floristics. J. Ecol. 51: 567-601.

Harper, J. L. 1977. Population biology of plants. Academic, New York. 892 pp.

Hietz, P. \& U. Hietz-Seifert. 1995. Structure and ecology of epiphyte communities of a cloud forest in central Veracruz, Mexico. J. Veg. Sci. 6: 719-728.

Hietz-Seifert U., P. Hietz \& S. Guevara. 1996 Epiphyte vegetation and diversity on remnant trees after forest clearance in southern Veracruz, Mexico. Biol. Cons. 75: $103-111$

Ingram S. W. \& N. M. Nadkarni. 1993. Composition and distribution of epiphytic organic matter in a neotropical cloud forest, Costa Rica. Biotropica 25: 370-383.

Johansson, D. 1974. Ecology of vascular epiphytes in West African rain forest. Acta Phytogeogr. Suec. 59: 1136.

Martin, C. E., N. L. Christensen and B. R. Strain. 1981. Seasonal patterns of growth, tissue acid fluctuations, and ${ }^{14} \mathrm{CO}_{2}$ uptake in the crassulacean acid metabolism epiphyte Tillandsia usneoides L. (Spanish moss). Oecologia 49: 322-328.
Medina, E., M. Delgado, J. H. Throughton \& J. D. Medina. 1977. Physiological ecology of $\mathrm{CO} 2$ fixation in Bromeliaceae. Flora 166: 137-152.

Murcia, C. 1995. Edge effects in fragmented forests: implications for conservation. TREE 10: 58-62.

Osmond, C. B., W. W. Adams \& S. D. Smith 1989. Crassulacean Acid Metabolism, p. 256-280. In R. W. Pearcy, J. R. Ehleringer, H. A. Money \& P. W. Rundel (eds.) Plant physiological ecology, Field methods and instrumentation. Chapman \& Hall, New York.

Richards P. W. 1952. The tropical rain forest. Cambridge University Press. Cambridge.

Turner, I. M., H. T. W. Tan, Y. C. Wee, A. B. Ibrahim, P. T. Chew \& R. T. Corlett. 1994. A study of plant species extinction in Singapore: lessons for the conservation of tropical biodiversity. Conserv. Biol. 8: 705-712.

Ter Steege H. \& J. H. C. Cornelissen. 1989. Distribution and ecology of vascular epiphytes in lowland rainforest of Guyana. Biotropica 21: 331-339.

Valdivia, P. E. 1977. Estudio botánico y ecológico de la región del río Uxpanapa, Veracruz No. 4. Las epífitas. Biotica 2: 55-81.

Walter, H. 1964. Die Vegetation der Erde in öko-physiologischer Betrachtung I. Die tropischen und subtropischen Zonen. Gustav Fischer. Jena.

Wolf, J. H. D. 1993. Diversity patterns and biomass of epiphytic bryophytes and lichens along an altitudinal gradient in the northern Andes. Ann. Missouri Bot. Gard 80: 928-960.

Wolf, J. H. D. 1994. Factors controlling the distribution of vascular and non-vascular epiphytes along an altitudinal gradient in the northern Andes. Vegetatio 112: 15-28.

Zimmerman, J. K. \& I. C. Olmsted. 1992. Host tree utilization by vascular epiphytes in a seasonally inundated forest (Tintal) in Mexico. Biotropica 24: 402408. 